\title{
Szolgálólányból királycsináló - avagy az ökonometria makroökonómiai térhódítása?
}

\begin{abstract}
Ez a cikk az ökonometria makroökonómiában betöltött szerepét tekinti át az elmúlt harminc-negyven esztendő távlatában. Azt a folyamatot próbálja megragadni, amelyben az ökonometria a segédtudományi szerepből egyre inkább kulcspozícióba került az újklasszikus makroökonómiában. Először a makroegyensúly potenciális kibocsátással való meghatározásának problémáival foglalkozik, kiemelve a becslés nehézségeit az egyensúlyi kibocsátás látens változóként való kezelésekor. Ezt követően a racionális várakozások ökonometriai modellezési gyakorlatát bírálja, azon az alapon, hogy korrekt makromodell nem alakítható ki az egész gazdaságra vonatkozóan, és így torzítatlan becslés sem valósítható meg. Végül a tanulmány az ökonometriai modelleken alapuló előrejelzések lehetőségét tárgyalja. Megállapítja, hogy ökonometriai becslésen alapuló hatásos elörejelzés nem lehetséges, mert a gazdaság makromüködése nem ergodikus folyamat, hanem útfüggő, s így nem határozható meg a gazdasági rendszer adatgeneráló folyamata. A cikk következtetése, hogy az ökonometriának az idősorelemzésektől vissza kellene térnie a keresztmetszeti elemzések és a mikroökonómiai megalapozásokat lehetővé tevő modellbecslésekhez.* Journal of Economic Literature (JEL) kód: C5, C53, D84, E17.
\end{abstract}

Az ökonometria a múlt évszázad harmincas éveiben alakult ki és erősödött meg a Cowles Commision védőszárnyai alatt. Kezdetben csak a közgazdaságtan segédtudománya volt, mintegy szolgálólányként igyekezett a tudományszak fejlődését elősegíteni. Az összegyüjtött statisztikai adatok alapján elkészített becslések jól illusztrálták az elméleti összefüggéseket, s ennek révén elősegítették a jobb megértést és a szélesebb körü felhasználást. Ahogy az elmélet-matematikai modell-empirikus igazolás „szentháromság” kutatási módszertan általánossá vált, úgy kapott egyre nagyobb szerepet az ökonometriai becslés. A tényadatok felhasználásán alapuló becslési eredmények komoly szelekciós kritériumot jelentettek: csak azok az elméleti tézisek

* A szerző ezúton mond köszönetet Balatoni Andrásnak, Körösi Gábornak, Németh Kristófnak, Rappai Gábornak, Váry Miklósnak és Világi Balázsnak értékes észrevételeikért és előremutató javaslataikért. Természetesen a tanulmányban előforduló hibákért kizárólag a szerző viseli a felelősséget.

Mellár Tamás egyetemi tanár, PTE Közgazdaságtudományi Kar.

A kézirat első változata 2016. január 12-én érkezett szerkesztőségünkbe.

DOI: http://dx.doi.org/10.18414/KSZ.2016.3.285 
(hipotézisek) tarthattak széles körü elfogadásra számot, amelyek kiállták a tényekkel való összevetés szigorú statisztikai próbáit. S ez már nem a szolgálólány, hanem annál lényegesen jelentősebb, döntőbíró-hitelesítő szerep.

Csakhogy ezt a döntőbírói szerepet az ökonometria nem volt képes maradéktalanul betölteni, ítéletei, megállapításai egyre gyakrabban kérdőjeleződtek meg, amikor más hasonló empirikus vizsgálatok homlokegyenest ellenkezö eredményekre vezettek. Aki egy kicsit is foglalkozott modellbecslésekkel, az jól tudja, hogy a becsléshez felhasználandó adatokat többnyire ki lehet úgy alakítani (az idősor hosszának, frekvenciájának megváltoztatásával, különféle deflálásokkal, trendhatások és kiugró adatok szürésével stb.), hogy igazolja vagy éppen cáfolja a szóban forgó hipotézist. Továbbá mindig lehet találni a sok-sok statisztikai próba közül néhány olyat, amely megbízhatónak, valamint persze olyat is, amely megbízhatatlannak tekinti a kapott becslési eredményeket. Nem véletlen, hogy a fóáramú közgazdaságtan vezető folyóiratában, a Journal of Economic Literature hasábjain is megjelenhetett olyan vélemény, amely szerint az ökonometriai abban a helyzetben van, hogy bármit és annak az ellenkezőjét is be tudja bizonyítani (Seater [1993]). Ebböl a kutyaszorítóból az ökonometria úgy tudott megmenekülni, hogy a kiszolgáló szerepböl egyre inkább a tudományszak meghatározójává vált. A mögöttünk hagyott két-három évtized azt mutatja, hogy az előremenekülés rendkívüli eredményes volt, az ökonometriai becslési és teszteljárási módszerek használata egyre általánosabbá vált. A forradalmi változás fö vesztese a makroökonómia (végső soron pedig a közgazdasági gondolkodás) lett, mert paradox módon egyre inkább elveszítette kapcsolatát a valósággal, pedig állandóan a szigorú empirikus igazolást hirdette, az ökonometria kiterjedt alkalmazása segítségével.

Hogyan jutottunk ebbe a helyzetbe? A hetvenes évek stagflációs válsága mintegy mellékhatásként a keynesizmust is megfosztotta a makroökonómiában betöltött vezetö szerepétől. Azt az elméletet, amelynek névadója, J. M. Keynes igen kemény kritikával illette a neoklasszikus közgazdaságtant, és használhatatlannak tartotta a makrogazdasági problémák, kiemelten a válságok kezelésének tekintetében. Viszont az elhúzódó stagflációs válság következtében a népszerüségét egyre inkább elveszítő keynesizmus lehetőséget kínált a neoklasszikus elmélet visszatérésére. Ez meg is történt: újklasszikus közgazdaságtan néven újjáéledt az optimálisan müködö, egyensúlyi piaci rendszer doktrínája. A régi-új elmélet elfogadtatásához valami olyan eszközre volt szükség, amely egzaktságával és empirikus tesztjeivel feledtetni tudta az 1929-1933-as világgazdasági válságot és Keynes megsemmisitő kritikáját. És itt jött be a képbe az ökonometria, amely az új tömlőt biztosította a neoklasszikusok régi borához, hogy immár új(klasszikus) nedűként eladhatóvá váljék. Az ökonometriai azért is bizonyult jó eszköznek, mert a keynesizmus éppen az ökonometriai makromodelljeivel bukott meg a leglátványosabban. A keynesi makroökonometriai modellek ugyanis minden kétséget kizáróan alkalmatlannak bizonyultak mind a gazdaságpolitikai elemzés, mind az elörejelzés feladatának ellátására.

A z újklasszikus makroökonómia számára azért vált kulcsfontosságúvá az ökonometriai módszerek kiterjedt használata, ha ugyanis demonstrálni tudják azt, hogy a racionális viselkedés és piaci egyensúly feltételeire alapozott ökonometriai 
modellek lényegesen jobb eredményeket adnak, mint a korábbi keynesi alapúak, akkor a neoklasszikus doktrína ismét szalonképessé válhat. Gőzerővel indult meg tehát a munka egy olyan makroökonometria kialakítására, amely ezeket a célokat teljesíteni tudta. Így került kifejlesztésre az újklasszikus ökonométerek által a Hodrick-Prescott-féle szürés, a racionális várakozások modellje, a kalibrálás stb. Az újklasszikus makroökonómia vizsgálati körébe egyre bonyolultabb becslési és módszertanilag kifinomultabb teszteljárások kerültek be, zömében olyanok, amelyek sikeresen megakadályozták, hogy a laikus (a matematikai-statisztikában kevésbé járatos, ám józan ésszel és gyakorlati érzékkel megáldott) felhasználók értékelni tudják az új modellek használhatóságát, illetve a piaci rendszer egyensúlyi és optimális jellegének empirikus bizonyítását.

Kapóra jött az újklasszikusok számára, hogy a nyolcvanas évek közepétől egy igen hosszú gazdasági fellendülés vette kezdetét, amely szinte automatikusan igazolta a piaci rendszer egyensúlyi jellegét és optimális müködését. Így aztán újabb és újabb ökonometriai modellek és teszteljárások láttak napvilágot, és váltak a föáramú makroökonómia teoretikus struktúrájának meghatározó elemeivé, az elmúlt 15-20 évben például a gazdasági ciklusok reálmodelljei (Real Business Cycle, $R B C$ ) és a dinamikus, sztochasztikus, általános egyensúlyi (Dynamic Stochastic General Equilibrium, $D S G E)$ modellek. Az ezredfordulóra ez a tudományszak vált a leginkább módszertanigényessé, az akkori átlagos matematikai és statisztikai ismeretekkel rendelkező közgazdászok számára pedig áttekinthetetlenné (Colander [2005]). A makroökonómia belterjessé vált, jószerével arról szólt, hogy az újklasszikus ökonométerek győzködték egymást a piaci rendszer tökéletes voltáról.

Az újklasszikus makroökonometriai modellek gyenge teljesítménye csak a 2008-as válság idején vált nyilvánvalóvá a széles közvélemény számára. Ezek a főáramú modellek ugyanis képtelenek voltak előre jelezni a gazdasági válságot (sőt még az egyensúlyi feszültségek felhalmozódásáról sem adtak számot), továbbá arra vonatkozóan sem tudtak semmi használhatót mondani, hogy miért alakult ki a válság, és mit is kellene valójában tennie a gazdaságpolitikának annak érdekében, hogy enyhítse a válság negatív hatásait. A fejlett országok igen kifinomult elméletekkel és ökonometriai modellekkel vizsgálódó közgazdászai sorra tértek vissza a régi, már meghaladottnak tekintett keynesi recepthez, és kezdtek aktivista fiskális és monetáris politikát folytatni, más épkézláb javaslat hiányában.

Mennyiben tehet arról az ökonométer szakma, hogy idáig fajultak a dolgok? Ezt a kérdést azért is érdemes itt elöljáróban feltenni, hogy világos legyen: ez a tanulmány nem az ökonometriai tudományszak egészéről szándékozik véleményt alkotni, hanem csak annak makrogazdasági alkalmazásairól. Az ökonometria nyilvánvalóan nem tehet arról, hogy az uralomra jutó újklasszikus közgazdaságtan csak az optimalizáló, egyensúlyi makroökonometriai modellek iránt érdeklődött, és nem vett tudomást a nem egyensúlyi, nem optimalizáló modellekröl, például a ökonometriai disequilibrium-modellekről (Quandt [1988]). Természetesen az sem írható a rovására, hogy a makroökonómia szisztematikusan válogatott a rendelkezésre álló teszteljárások között, aszerint hogy az érdeke mit követelt meg. Arról viszont már igen is tehetett, hogy a célirányosan kifejlesztett becslési módszerek és eljárások szakszerű 
kritikáját nem adta meg, és hagyta, hogy ezek a bizonytalan teszteljárások döntő jelentőségűekké váljanak alapvető makroökonómiai tételek elfogadásában vagy elvetésében, és ezáltal fetisizált, döntőbírói, királycsináló szerepbe kerülhessen a makroökonometria. Ezzel ugyanis nemcsak a makroökonómia presztízse csökkent, hanem az ökonometriáé is.

A következőkben két olyan területet vizsgálunk meg, ahol tetten érhető módon az ökonometria alakította a makroökonómia teoretikus struktúráját. Az egyik ilyen kiemelten fontos terület a potenciális kibocsátás és a kibocsátási rés (output gap) témaköre, a másik pedig a racionális várakozások elmélete. Majd ezt követően arra a kérdésre próbálunk választ adni, hogy lehetséges-e ökonometriai modellek alapján hatásos elörejelzéseket készíteni.

\section{Potenciális kibocsátás, avagy mit mutat a trend, és mit nem?}

Tekintsük az 1. ábrán a magyar gazdasági összteljesítmény, a reál-GDP alakulását negyedévenként!

\section{1. ábra}

A GDP alakulása és lineáris trendje, 1995-2015* (negyedéves adatok, ezermilliárd forint, 2005. évi átlagáron)

Ezermilliárd forint

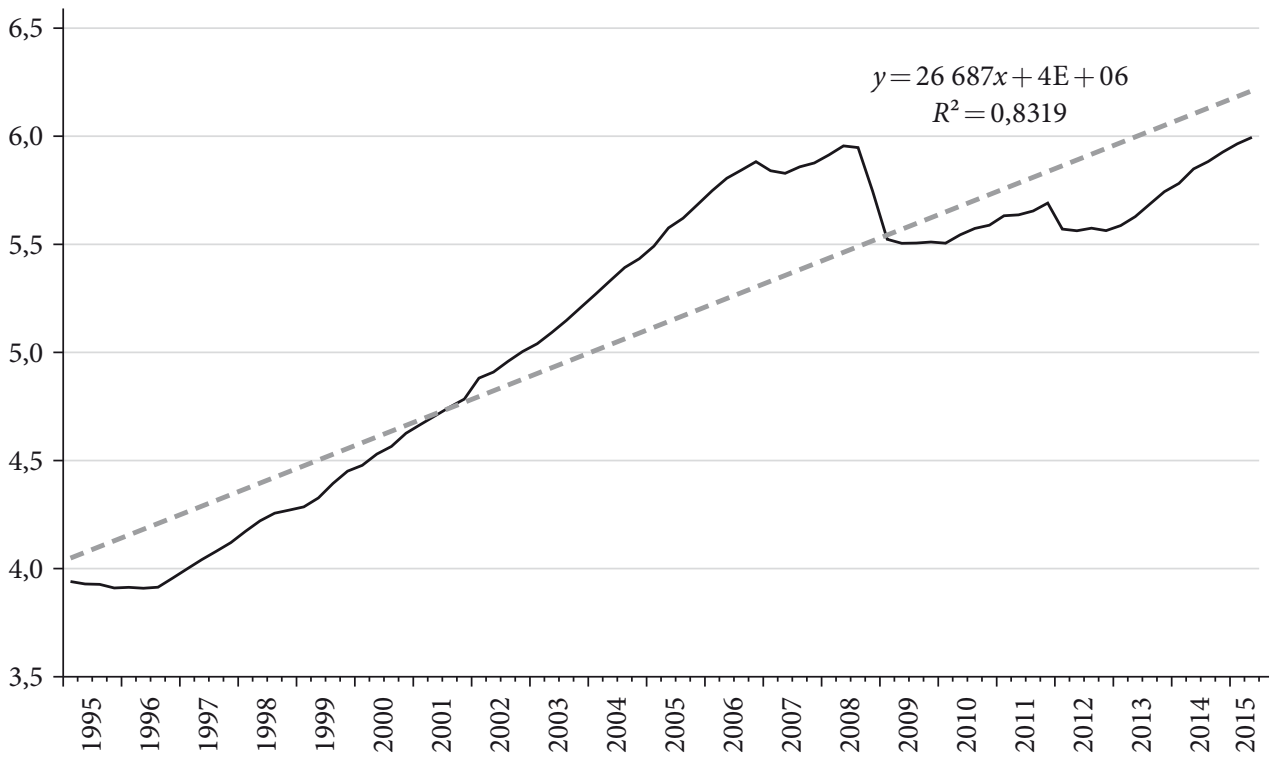

* Szezonálisan és naptári hatással kiigazított és kiegyensúlyozott adatok.

Forrás: a KSH nyilvános adatbázisa alapján Németh Kristóf szerkesztése.

Ez az adatsor a modern ökonometria és a fóáramú makroökonómia által kevéssé befolyásolt (mondjuk posztkeynesiánus) közgazdász számára azt jelzi, hogy íme így 
teljesített a magyar gazdaság a jelzett 1995-2015 közötti időszakban. Ezt az adatsort teljesen egyedinek tartja, olyannak, amely csak az adott gazdaságra és csak a vizsgált időszakra jellemzö. Nem feltételezi, hogy előtte is ugyanilyen mintázatok érvényesültek a kibocsátási értékekben, azt pedig végképpen nem gondolja, hogy ugyanezek a növekedési sajátosságok fognak a jövőben is érvényesülni. Nem próbál bármifajta általános összefüggést keresni az idősor alakulására vonatkozóan, mert az gondolja, hogy minden egyes időszakban más és más tényezőegyüttesek alakították ki a végeredményt. Szerinte lehetetlen a makromüködés egészét meghatározó nagyszámú tényezőből kiválasztani néhányat, és azok alapján általános érvényü mozgásegyenletet konstruálni, amely előre és hátra egyaránt jól magyarázza a konkrét makrogazdasági történéseket. Számára a bemutatott idősor sokkal egyszerübb (más szempontból pedig sokkal bonyolultabb) feladatot jelöl ki: konkrétan azt megmagyarázni, hogy egy adott időszakban miért úgy alakult a gazdasági teljesítmény, akkor milyen tényezők játszottak döntő szerepet, az induló állapot mennyire volt meghatározó abban, hogy növekedés vagy csökkenés valósult meg. S persze továbbmenve még az is feladata lehet, hogy azt is feltárja, melyek azok a tényezők, amelyek várhatóan a következő időszakban is befolyással lesznek majd, s melyek azok, amelyek már nem játszanak meghatározó szerepet a növekedés alakításában.

Összefoglalva tehát, a föáramú makroökonómia által kevéssé befolyásolt közgazdászt nem a teljes idősor meghatározottsága érdekli, hanem csak az, hogy a megelőző időszak bázisán miként alakult ki az adott helyzet, s hogy ebből a speciális állapotból milyen áthúzódó pozitív és negatív hatások keletkezhetnek, amelyek befolyást gyakorolnak a következő időszak teljesítményének alakulására.

Nem így gondolkodik azonban a föáramú makroökonómián nevelkedett közgazdász. Számára ez az idősor egy jól azonosítható (nevezetesen a magyar) gazdaság makroteljesítményeit mutatja különböző időszakokra vonatkozóan, vagyis egy konkrét (jól definiált) gazdasági rendszer működésének eredménysora. Mivel itt végig ugyanarról a gazdaságról van szó, amelynek szerkezete és mủködési módja csak nagyon lassan és nagyon kis mértékben változik időben, ezért az idősor elemeit egy homogén adategyüttesnek tekinti. Az elemzők többnyire azt feltételezik, hogy az összegyüjtött sok-sok tényadat jól visszatükrözi a gazdaság valós teljesítményét, végső soron az válik dominánssá, és nem az esetlegesség. Ezért aztán kézenfekvőnek találja, hogy trendet illesszen az idősor adataira (lásd az 1. ábrát). A trendpálya azt hivatott megmutatni, hogy az egész időszakot tekintve milyen is volt a gazdasági teljesítmény meghatározó mozgásiránya és mértéke. Egy ilyen trendszámításnak mindenképpen van létjogosultsága, és bizonyos szempontból hasznos is lehet, mert nemcsak az egész időszak fö tendenciáját mutatja meg, hanem azt is, hogy az egyes idöszakokban a teljesítmény elmaradt, vagy éppen meghaladta azt a trendértéket, amely az egész időszakra általánosan jellemző.

De vajon miért alakultak ki a trendtöl való eltérések a különböző időszakokban? A kézenfekvő válasz erre a kérdésre, hogy azért, mert a szokásos normális müködést valamilyen véletlen tényező (külső sokk) megzavarta, és így a gazdasági teljesítmény nem a jogosan várható (trend)értéknek megfelelően alakult. Ez a válasz azonban nem kielégítö, mindenekelőtt azért nem, mert egy teljesen stabil, állandó 
gazdasági struktúrát tételez fel. A makrogazdasági szerkezet azonban távolról sem stabil, időben nagyon is változó, két szempontból is. Egyfelől azért, mert a gazdaság makrostruktúrája nem állandó, hanem időben nagyon is változó. Hiszen állandóan változik a gazdasági szereplők száma és összetétele, az intézmények száma és egymáshoz való viszonyuk, az adminisztratív szabályozás rendszere stb. Másfelől pedig még ha állandónak tételeznénk is a struktúrát, akkor is megmaradna az a probléma, hogy egy olyan bonyolult rendszerben, mint a nemzetgazdaság, ahol jelentős menynyiségü tényező határozza meg a GDP eredményváltozót, az egyes tényezők hatása időben jelentősen változhat. Egy adott időszakban mondjuk a $k_{1}, k_{2}$ és $k_{3}$ tényezők játszottak meghatározó szerepet, míg a másik időszakban a $k_{2}, k_{5}$ és $k_{6}$ tényezők. A gyakorlatban ez úgy mutatkozik meg, hogy például megváltoznak a gazdasági szereplők viselkedési szabályai, normái, napi rutinjai.

Az ökonometriában jártas olvasó itt közbevethetné, hogy az imént említett probléma nem is az valójában, mert a rezsimváltó (lásd bővebben Rappai [2014]) és az időben változó együtthatójú modellek (Varga [2010]) jól tudják kezelni az ilyen helyzeteket. Ha azonban alaposabban megnézzük ezeket a modelleket, akkor azt láthatjuk, hogy a korrekciós eljárások alapja rendre valamilyen a priori feltételezés arra vonatkozóan, hogy miként változnak a becsült paraméterértékek, vagy hogyan módosulnak a becslőfügg vények bizonyos határértékek elérése vagy rezsimváltozások bekövetkezése esetén, lásd például a küszöb- (Treshold Autoregressive, TAR) és a sima átmenet (Smooth Transition Autoregressive, STAR) autoregresszív modelleket. Olyan átmeneti valószínüségeket, küszöbértékeket határoznak meg a múltbeli adatok alapján, amelyek korábban relevánsnak bizonyultak, $s$ amelyekről éppen ezért azt tételezik fel, hogy a jövőben is változatlan módon fognak müködni. Sajnos azonban a gazdasági rezsimek váltásának sincs könnyen meghatározható menetrendje, ezért a határozatlanság továbbra is fennáll.

Ezért tehát az, amit a trendszámítás logikája külső véletlen, zavaró hatásnak tekint, az könnyen elképzelhető, hogy nagyon is belső tényezők által determinált, s olyan szerkezeti és viselkedési változásokra vezethető vissza, amelyeket ez az eljárás nem tud meghatározni. Ez annál is inkább valószínű, hiszen a trendértéktől való jelentős pozitív és negatív eltérések külső zavaró tényezőkkel való indoklása nagyon kényszeredett, hiszen nem világos, hogy milyen tényezőket tekinthetünk zavaróknak, és ezek változása számszerüen mekkora hatást gyakorolhat a GDP-re. Igen nehezen lehetne az átmeneti sokkok alapján megmagyarázni a 2002-2008 közötti jelentős és igen tartós pozitív, majd a 2009 utáni jelentős negatív eltéréseket. Hivatkozhatunk ugyan az első esetben a kormányzat erőteljes élénkítő tevékenységére, míg a második esetben a világválság visszafogó hatására, azonban mindkét esetben fel kell tenni a nagy kérdést: hol maradt a piaci rendszer önszabályozó mechanizmusa? Ha ilyen sokáig nem téríti vissza a gazdaságot a megszokott pályára, akkor lehet, hogy a trend által kijelölt pálya nem is olyan stabil, lehet, hogy a sokkok nem átmenetinek, hanem tartósnak bizonyulnak és ezért maga a trend pálya is megváltozik?

A nagy trendeltérések nehézkes magyarázata arra indította az ökonométereket, hogy segítséget nyújtsanak a makroökonómiával foglalkozó társaiknak, mégpedig a már említett HP-trend (és -szürö) segítségével. (Természetesen más trendszámítási 
eljárások is rendelkezésre álltak, talán a viszonylagos egyszerűsége miatt választották ezt az eljárást a közgazdász-ökonométerek.) Hodrick-Prescott [1997] egy olyan trendszámítási metódust ajánlott, amelyben a becslést végző, a későbbi felhasználó saját maga kalibrálhatja be a trendtől való eltérések nagyságrendjét. Célirányos paraméterezéssel (a $\lambda$ paraméterérték beállításával) könnyen elérhetö, hogy az elég nagy eltéréseket tartalmazó idősor esetén is csak kis trendeltérések legyenek, ugyanis a paraméterezésnek megfelelően ilyenkor a HP-trend alakja eröteljesebben alkalmazkodik a tényszámokhoz, mint a tradicionális egyenes vonalú trendhez. Ez viszont egy újabb önkényes elemet visz a makroteljesítmények magyarázata tárgykörbe. A 2. ábra jól mutatja, hogy a másfajta trendszámításnak köszönhetően most sokkal kisebbek lettek a „külső zavaró hatások”, a sokkok kevésbé mozdították el a gazdaságot a normális pályájától - legalábbis a HP-szűrő szerinti trendszámítás alapján erre a konklúzióra juthatunk.

\section{2. ábra}

A GDP alakulása és HP-trendje, 1995-2015* (negyedéves adatok, ezermilliárd forint, 2005. évi átlagáron)

Ezermilliárd forint

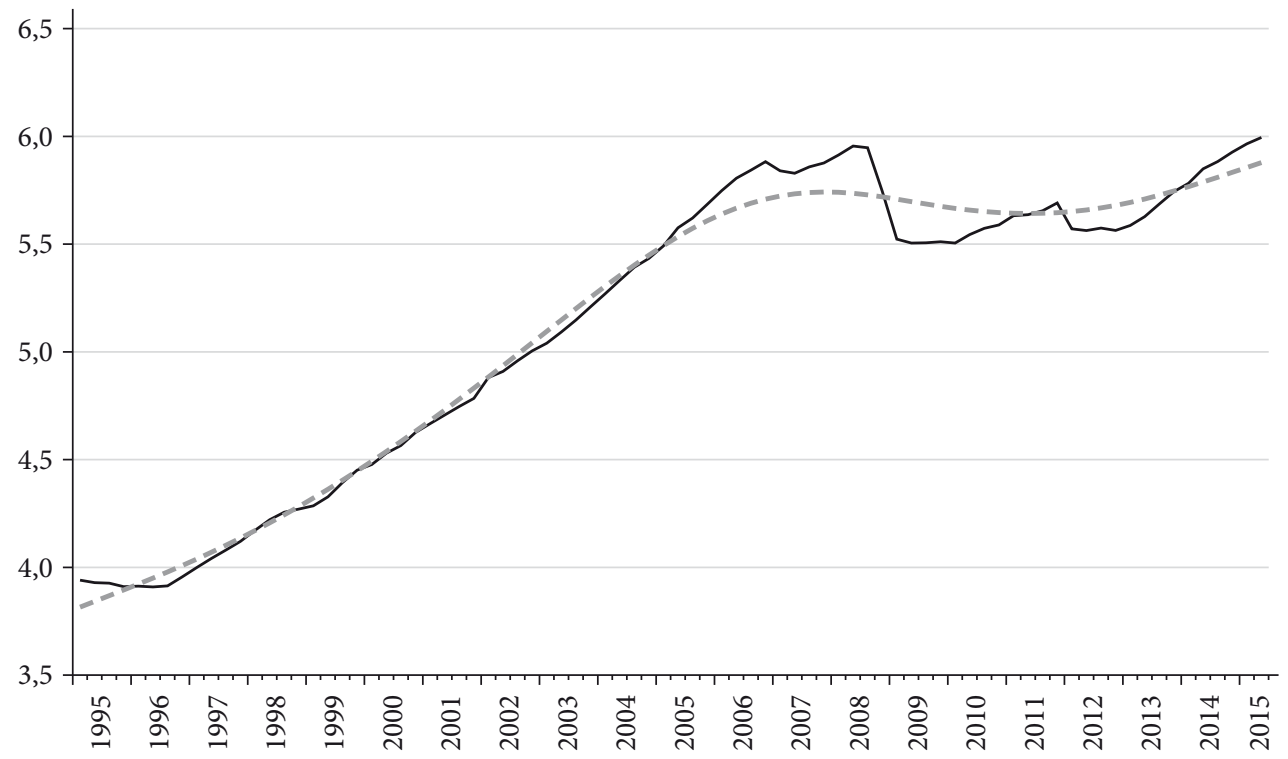

* Szezonálisan és naptári hatással kiigazított és kiegyensúlyozott adatok.

Forrás: a KSH nyilvános adatbázisa alapján Németh Kristóf szerkesztése.

A trendszámítás különböző módszerei közötti választás azonban nem maradt meg az ökonometriai szakterületén, hanem a makroökonómiába is beszüremkedett, és igen fontos szerepet kezdett játszani. Erre azért kerülhetett sor, mert a GDP idősorára illesztett trendet a fóáramú kutatók egyre határozottabban egyensúlyi (potenciális kibocsátási, fenntartható növekedési stb.) pályaként kezdték értelmezni. Az átértelmezés indoklása elég egyszerü, ugyanis, ha 1. a trend a gazdasági müködés 
alapirányzatát mutatja, s mivel 2. az összmüködés alapirányát a piaci mechanizmus határozza meg, akkor 3. a trendérték a piaci egyensúlyi helyzetet jeleníti meg. Így a trendértékektől való eltérések kiemelt szerepkörbe kerültek, s önálló nevet is kaptak: kibocsátási rés (output gap).

A kibocsátási rés miatt a külső zavaró tényezőket okolták, amelynek nagysága az egyensúlytalanság mértékét tükrözi. Tehát ha egy adott időszakra a trendszámítások alapján azt találjuk, hogy a tényleges érték mondjuk 3 százalékkal haladta meg a trend- (potenciális kibocsátási) értéket, akkor ez azt jelenti, hogy a gazdaságban ilyen arányú aggregált kereslettöbblet keletkezett. Továbbmenve, ez a kereslettöbblet a munkapiacon is megnyilvánul a foglalkoztatás növekedése (és a munkanélküliség csökkenése) formájában. Az aktuális munkanélküliségi ráta ilyenkor a természetes ráta szintje alá kerül. (Ha valaki most megkérdezi, hogy a munkanélküliség természetes rátája mekkora, és hogyan határozódik meg, akkor ugyancsak a trendszámításhoz utalnak bennünket a fóáram hívei, ugyanis az nem más, mint a munkanélküliségi ráták idősorára illesztett HP-trend.)

A kibocsátási rés természetesen az inflációra is hatást gyakorol, hiszen a kereslettöbblet inflációs nyomást jelent. Így az infláció és munkanélküliség közötti kapcsolatot leíró Phillips-görbe helyett egyre gyakrabban használják a makroelemzéseknél az infláció és a kibocsátási rés közötti kapcsolatot. De nemcsak az elemzéseknél, hanem a monetáris politika területén is jelentős szerepet kapott ez az összefüggés. A fenti logika szerint pozitív kibocsátási rés esetén a monetáris hatóság inflációs nyomást diagnosztizál, ezért a jegybanki alapkamat növelését kezdeményezi, feltéve, ha az aktuális infláció értéke nem jelentősen alacsonyabb az inflációs cél értékénél. Fordított esetben, azaz negatív kibocsátási rés esetén a jegybank kamatcsökkentést indít, hacsak nem ragadt be az infláció egy, a célértéknél magasabb szinten. Az elmúlt évtizedekben egyre általánosabbá vált, hogy a föirányú makroökonómia a meghatározó makroösszefüggéseket a „kamatláb-infláció-kibocsátási rés” hármasa által definiálja: 1. a kamatláb meghatározza a kibocsátási rést (IS görbe), 2. a kibocsátási rés pedig az inflációt (módosított Phillips-görbe), 3. a kamatlábat pedig a monetáris hatóság az infláció (pontosabban a célértéktől való eltérése) és a kibocsátási rés alapján állítja be (Taylor-szabály).

Ez az elméleti konstrukció azonban igen bizonytalan lábakon áll, mivel a potenciális kibocsátás és a kibocsátási rés nem közvetlenül megfigyelhetö, hanem látens változó, amelynek meghatározásához mindig bizonyos feltételezésekkel kell élni. Ugyanakkor pedig a közgazdasági és a gazdaságpolitikai értékelések jelentős mértékben függnek attól, hogy a kibocsátási résre vonatkozóan milyen becslési eredmények állnak rendelkezésre. A HP-trend alakja (és így a kibocsátási rés számított értékei) nemcsak a különféle paraméterezés ( $\lambda$ értékeinek változtatása) révén változhat, hanem az idősor egészére vonatkozó ismeretek szintje szerint is. A 2. ábrán látható HP-trend számításához ismert volt a teljes idősor 1995-től 2015-ig. Egészen más lett volna a számított trend alakja, ha, mondjuk, csak 2007 negyedik negyedévéig terjedő időszakra kalkuláltuk volna, mégpedig úgy, hogy csak az 1995-2007 közötti GDP-adatok álltak volna rendelkezésre. Ebben az időszakban ugyanis még nem volt előre látható, hogy 2008-ban jelentős visszaesés lesz, s ez természetszerüen 
lényegesen befolyásolta a HP-trend konkrét alakját. A magyar gazdaságpolitikai gyakorlatban ez a torzító hatás úgy jelentkezett, hogy 2006-2007-ben még szinte minden elemzés azt állapította meg, hogy a magyar gazdaság a fenntartható egyensúlyi pályán van, s nincs számottevő pozitív kibocsátási rés, tehát nyugodtan folytatható a laza fiskális politika. A 2010 utáni információs bázison kalkulált trendek viszont már egyértelmüen arra mutattak rá, hogy a 2004-2008 közötti időszakban a gazdasági növekedés jóval az egyensúlyi szint felett volt, a kibocsátási rés a plusz 2-4 százalékos sávban mozgott (lásd a 3. ábra ex post filterezés adatait).

\section{3. ábra}

HP-szürőben becsült kibocsátási rés különböző információs bázisok mellett, 1995-2015

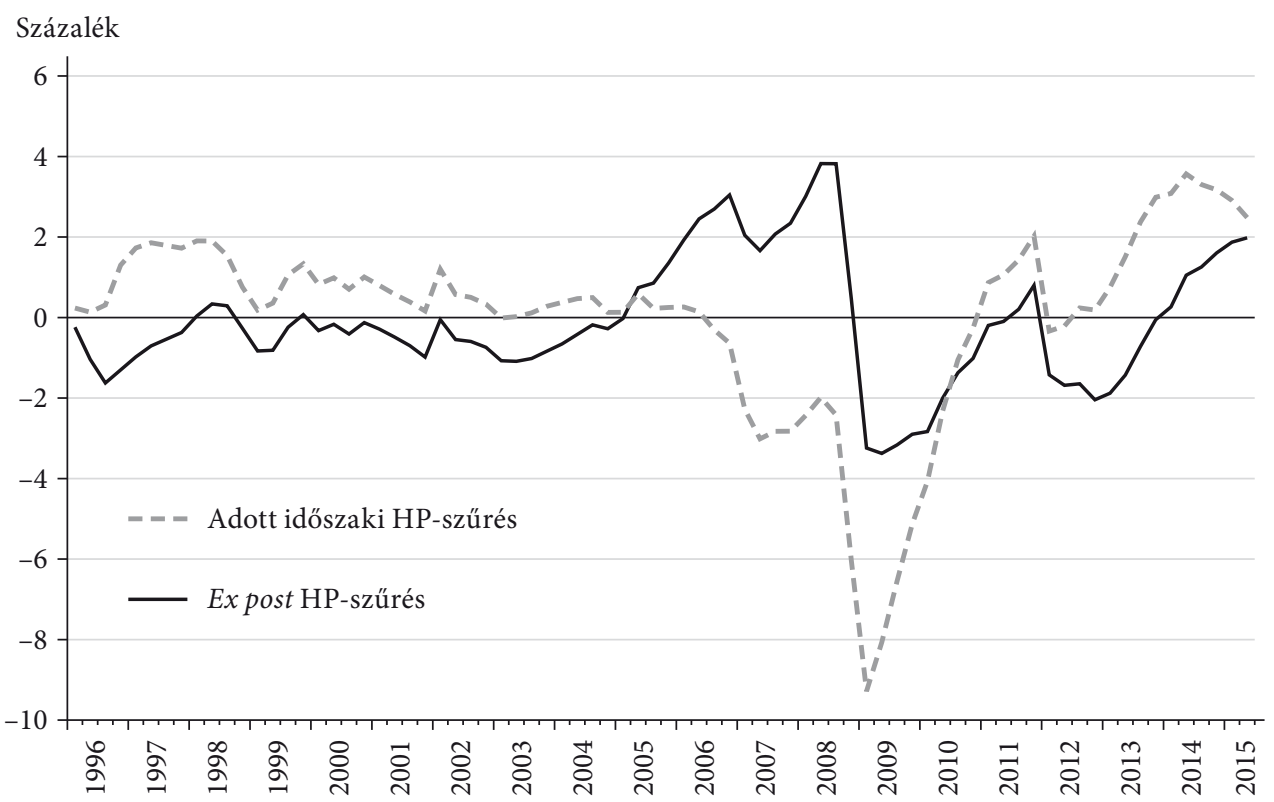

Forrás: a KSH nyilvános adatbázisa alapján Németh Kristóf szerkesztése.

Utólag persze már egészen másként alakulnak a dolgok, mint menet közben, a folyamatok kellős közepén. Jól mutatja ezt a triviális igazságot a 3. ábra, ahol a kibocsátási rések becslését egyfelől az adott időszak információs bázisán (adott időszaki HP-filterezés) és az időszak végén rendelkezésre álló információk alapján (ex post HP-filterezés) végeztük el. A különbség a két becslés között igen nagy, különösen a válság kitörését megelöző éveket tekintve. Jó lett volna 2006-ban vagy 2007-ben azt tudni, hogy a kibocsátási rés nem negatív, hanem erőteljesen pozitív, tehát a gazdaságpolitikának nem élénkíteni, hanem inkább visszafogni kellett volna. Érdemes fellapozni az MNB 2006-2007-es inflációs jelentéseit, ahol minden negyedévben becslést adtak arra, hogy a GDP növekedési üteme milyen tartományba fog esni a következő 4-6. negyedévben (ezek az úgynevezett legyezőábrák). A későbbi tényadatok egészen mást mutattak, mint amit az aktuális trend meghosszabbítása révén a szakértők előre jeleztek. Az eltérések esetenként óriásiak voltak, például 2007 elején 2009 harmadik 
negyedévére 1,5 és 5,5 százalék közé jelezték elöre a GDP növekedését ( $M N B$ [2007] 9. o.), ehhez képest valójában 7,6 százalékos csökkenés valósult meg. Ezek a fiaskók arra világítanak rá, hogy az egyensúlyi makropálya trendalapú becslése nem kielégítő. Fontos hangsúlyozni, hogy a durva becslési hibák nemcsak a világválság kitörése miatt következtek be, hanem azért, mert hibásnak bizonyult az az alapkoncepció, amely a makroegyensúlyt a trendértékkel meghatározhatónak vélte.

A potenciális kibocsátási pálya trendtípusú meghatározása mellett elindult egy olyan irányzat is, amely termelési oldalról, termelési függvény segítségével kívánta meghatározni a potenciális kibocsátást. A kibocsátás nyilvánvalóan a rendelkezésre álló termelési tényezők mennyiségétől, azok kihasználtsági szintjétől és hatékonyságától függ. A potenciális kibocsátás meghatározásához ismerni kell azokat a kihasználtsági szinteket és tényezőhatékonyságokat, amelyek egyensúlyinak (normálisnak, átlagosnak) tekinthetők, amely szintek mellett nem halmozódnak fel különféle feszültségek a gazdaságban. Ezeket a kihasználtsági szinteket és hatékonyságnövekedéseket - a meghatározásukhoz szükséges információk híján - a becslést végzők általában trendszámítással határozták meg. A leggyakrabban használt Cobb-Douglas-típusú termelési függvényben az aktív népességet gyakran korrigálják az inflációt nem gerjesztő munkanélküliségi rátával (Non Accelerating Inflation Rate of Unemployment, NAIRU), ami definíció szerint akár egyensúlyinak is tekinthetnénk, hiszen azt ígéri, hogy ez a munkanélküliségi szint, amely mellett az infláció nem gyorsul fel, de a származtatása szinte kivétel nélkül minden esetben a munkanélküliség HP-trendje. Ugyanez a helyzet a teljes tényezőtermelékenységgel (Total Factor Productivity, TFP) is, mivel a potenciális kibocsátás számításánál - statisztikai adat híján - a számított HP-trendértékkel kalkulálnak (lásd bővebben Mellár [2015] 274-282. o.). S ezzel visszajutottunk az előző részekben taglalt trendszámítási problémához.

Az elmúlt évek örvendetes új fejleménye, hogy a potenciális kibocsátás és kibocsátási rés számítása elszakadni látszik az egydimenziós jellegtől (kibocsátási rés $=$ inflációs nyomás), és tágabb értelmezést nyer a makroegyensúly. Ebben az elmozdulásban nyilván komoly szerepet játszott a válság tapasztalata, nevezetesen az, hogy akkor is túlfütötté válhat a gazdaság, ha egyáltalán nincs infláció és inflációs nyomás. Az Egyesült Államokban úgy alakult ki egy óriási ingatlanpiaci buborék, hogy mindeközben az infláció 2 százalék körül mozgott. Több európai országban pedig azt tapasztalták, hogy a viszonylag alacsony infláció és ezért egyensúlyinak vélt növekedés mellett a gazdasági szereplők óriási mértékben adósodtak el, és tették ezzel a pénzügyi piacokat labilissá, majd ezen keresztül sebezhetővé az egész makrogazdaságot. A fóáramú makroökonómia rákényszerült, hogy vizsgálati körébe a pénzügyi piacokat is beemelje, hiszen a hitelpiaci boom, a tömeges eladósodás és a hiteláttétel drámai változásának figyelmen kívül hagyásával aligha magyarázható kielégítően a válság kirobbanása és az azt követő alkalmazkodási folyamat. A potenciális kibocsátás becslésére alapozott RBC és DSGE modellek rendre csődöt mondtak a válság előrejelzésekor és magyarázatakor.

Az ökonometria azonban ismét a makroökonómia segítségére sietett. Egy olyan módszert kínált, amely több - a makroegyensúly szempontjából fontos, 
meghatározó - tényező (indikátor) alakulása alapján határozza meg az egyensúlyi pályát. A Kálmán-szürő segítségével olyan GDP-értékeket választanak potenciálisnak, amelyek esetén a legkisebb lesz az egyes tényezők (az államháztartási és a folyó fizetési mérleg hiánya, az eladósodottság, a kapacitáskihasználtság, a munkanélküliség stb.) eltérése a saját normál- vagy egyensúlyi értékeiktől. A korábban említett potenciális (egyensúlyi) pálya meghatározásokhoz képest ez sokkal jobb, mert tekintettel van arra, hogy a makroegyensúly (ha egyáltalán van ilyen) többdimenziós jellegü (a 4. ábra mutatja a kibocsátási rés Kálmán-szürő alkalmazásával végzett becslésének eredményeit a hagyományos HP-szürős becsléssel összevetve).

\section{4. ábra}

A kibocsátási rés különböző modellekben becsült idősorai

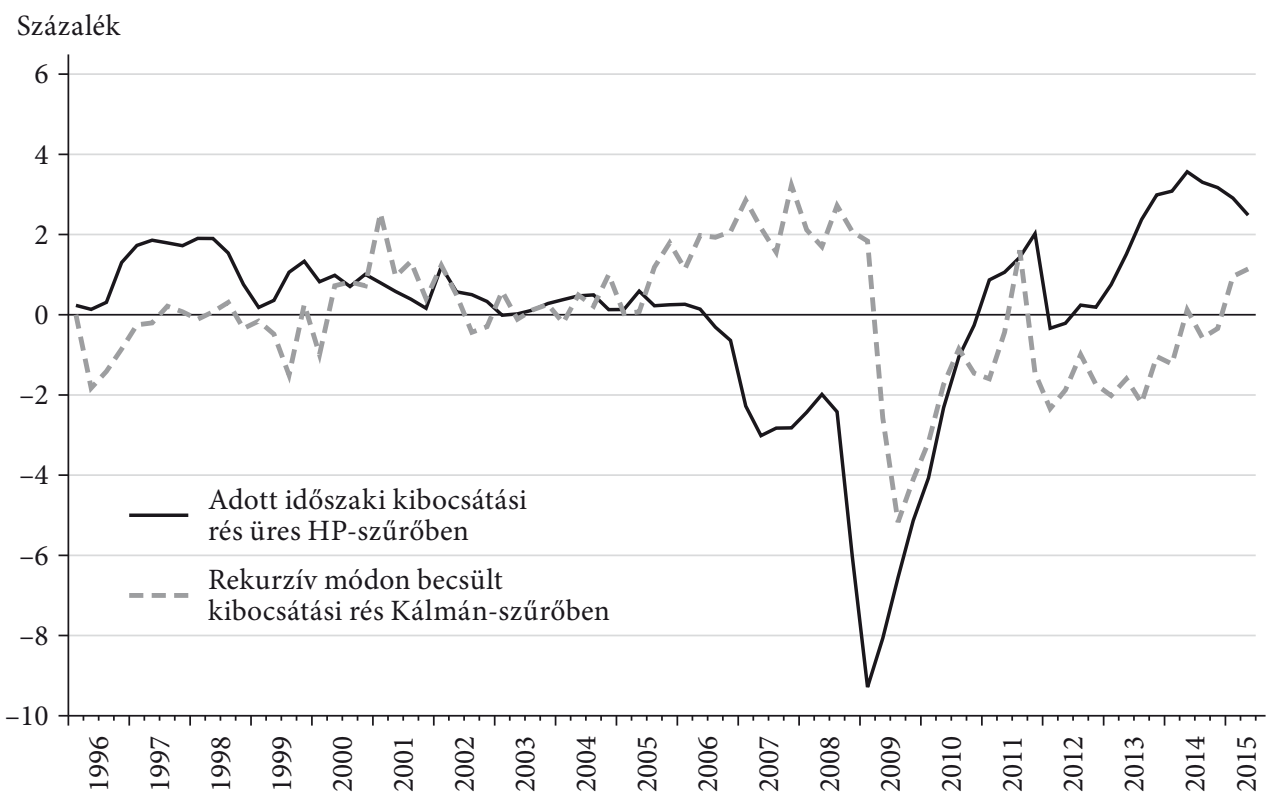

Forrás: a KSH nyilvános adatbázisa alapján Németh Kristóf szerkesztése.

A Kálmán-szürő alkalmazásához általában nincs szükség az egyes magyarázó tényezők mintabeli egyensúlyi értékeire (tehát a HP-trenddel kapcsolatos probléma kivédhető), mivel az algoritmus egy rekurzív lineáris közelítés. Ha azonban a kibocsátási rés közgazdaságilag releváns becslését szeretnénk megkapni, akkor már szükséges az exogén magyarázó változók valamilyen egyensúlyi értékeinek ismerete (Borio és szerzőtársai [2013]). Az egyensúlyi értékek meghatározásánál viszont ismét beleütközünk az egész mintára vonatkozó trendmeghatározás problémájába. Nyilván más eredményt kapunk, ha például az átlagos kapacitáskihasználás szintjét egyszerü átlagolással számítjuk, vagy ha HP-trend alapján.

További problémát jelent, hogy az egyes tényezők (illetve azok egyensúlytól való eltérései) milyen súllyal legyenek figyelembe véve a potenciális pálya meghatározásánál. Itt is jelentkezik a szubjektív elem, mert megint csak nincs elméleti alap 
a helyes súlyarányok beállítására. Ráadásul még azzal is számolni kell, hogy ezek a súlyok menet közben is változhatnak. Például egészen más a jelentősége (relatív fontossága) az eladósodottság mértékének a konjunktúra felfelé ívelő szakaszában, mint a válság kitörése után. A specifikációra nagyon érzékeny modellek jó valós idejü becslési teljesítményéhez nagyon hosszú, több konjunktúraciklust is magában foglaló (homogén) makroidősorokra lenne szükség. Ilyen azonban a legtöbb nemzetgazdaság esetében nem áll rendelkezésre.

\section{A racionális várakozások térhódítása}

Az újklasszikus közgazdaságtan a múlt század hetvenes éveiben a racionális várakozások elméletével és módszertani alkalmazásaival robbant be az akadémiai közgazdaságtanba és szorította ki fokozatosan a keynesi alapokon álló makroökonómiát. Az akkori időszak elhúzódó stagnálása, amely jelentős inflációval társult, az érdeklődés középpontjába helyezte a várakozások kérdését. A gazdasági szereplők pesszimista várakozásaival magyarázták, hogy miért nem indul be a fellendülés a kormányzatok élénkítő politikája ellenére. Muth [1961] cikke után többféle várakozási típus is ismertté vált: naiv, statikus, adaptív és racionális várakozások. Ezek közül Robert Lucas nevéhez köthető racionális várakozásokat választották ki, mindenekelőtt azért, mert ezzel vélték kiváltani a klasszikus-neoklasszikus közgazdaságtan tökéletes informáltságra vonatkozó feltételezését, amelyet ők is eltúlzottnak gondoltak. Így aztán az újklasszikus makroökonómia az 1. optimalizáló gazdasági szereplők, a 2. piactisztító árak és a 3. racionális várakozások pilléreire épült.

A közismert definíciók szerint akkor tekintjük a várakozásokat racionálisnak, ha a várt érték $\left(X^{e}\right)$ és a tényleges érték $(X)$ közötti különbség várható értéke nulla $\left[\mathrm{E}\left(X^{e}-X\right)=0\right]$. Másként fogalmazva ez azt jelenti, hogy az ilyen várakozás (elörejelzés) esetén nincs szisztematikus becslési hiba, a várt érték és a tényleges érték csak a véletlen zavaró hatások miatt térhet el egymástól. Ez a kívánatos helyzet azért állhat elö, mert a várakozásra vonatkozó becslést olyan modellből nyerték, a mely „adekvát módon jellemzi” a szóban forgó változó mozgását. Az adekvát becslési modell használatának következménye, hogy itt a véletlen „jól viselkedö”, nulla várható értékű, konstans szórású normális eloszlású valószínűségi változóval jellemezhető. Könnyen észrevehető, hogy az így definiált racionális várakozás triumfálja az összes többi, szóba jöhető várakozást, hiszen a többiek bizonyosan torzított becslést adnak, míg itt a helyes modellen alapuló becslés következtében kizárt a torzítás. A kérdés ezek után már csak az, hogy milyen körben alkalmazhatjuk a racionális várakozásra épülö módszereket.

Vegyük példaként azt a helyzetet, hogy valaki mindennap abszolút szabályos módon feldob 100 darab szabályos érmét, és azt kell megmondani, hogy várhatóan ebből mennyi lesz fej! Erre az esetre tökéletesen lehet alkalmazni a racionális várakozások elméletét. Ismerjük a jelenség adekvát modelljét, és ennek alapján könnyen meg tudjuk határozni a fejdobások várható számát. Így aztán az egyes napokon a tényleges fejdobások száma és az általunk racionálisan várt 50 darabtól való eltérés valóban ,jól 
viselkedő" véletlen lesz, nulla várható értékkel és konstans szórással. A modellünk akkor is használható lesz, ha a feladat annyiban módosul, hogy az emberünk mindennap egy kicsivel (mondjuk, kis ingadozásokkal, átlagosan 5 százalékkal) több pénzérmét dob fel, mint előző nap. A racionális várakozások modellje ekkor is kiválóan fog müködni. Módosítsuk most úgy a feladatunkat, hogy két különböző feldobó ember váltogatja egymást, s az egyikről azt lehet tudni, hogy ő 100 feldobásból átlagosan 60 fejet és 40 írást produkál (mert mondjuk, nem szabályos érméket használ). A másik feldobó ember továbbra is szabályosan 50-50 alapon müködik. Tegyük fel továbbá, hogy a két feldobó ember véletlenszerúen váltja egymást. Amennyiben ismert vagy megismerhetö, hogy a két ember milyen gyakorisági rendben váltja egymást (vagyis ismert az átmeneti valószínűségek Markov-folyamata) és az átmeneti valószínűségek konstansak, akkor továbbra is alkalmazható a racionális várakozások modellje, ugyanis a folyamatnak létezik állandósult állapota, a véletlen pénzfeldobási folyamat valószínüségeloszlása egy hosszú távú változatlan (ergodikus) eloszláshoz tart.

A gazdasági életben azonban nem nagyon lehet találni olyan folyamatokat, amelyek az imént leírtaknak megfelelően, stabil tulajdonságokkal rendelkeznének. Különösen igaz ez a makroszintre, ahol szinte kizárólag összetett és változékony folyamatokkal találkozhatunk. A racionális várakozások hipotézise gyors és széles körü elterjedését éppen annak köszönhette, hogy olyan fontos makrováltozók becslésére alkalmazták, mint az infláció és a gazdasági növekedés. Az inflációs várakozások fontosságát az adja meg, hogy amennyiben a gazdasági szereplők megbízható információval rendelkeznek az árszínvonal alakulásáról, akkor az optimalizáló döntéseik az egyensúlyi reálarányokat (reálbér, reálkamatláb) fogja beállítani. S így a gazdasági szereplők racionális döntései alapján a makrogazdaság a hosszú távú egyensúlyi pályán fog maradni.

A racionális várakozások makroökonómiai karrierje minden bizonnyal Lucas [1976] híres kritikájával alapozódott meg (bár a „forradalom” nem ezzel kezdődött, hanem Lucas 1972-1973-as írásaival). Ebben a tanulmányban megsemmisítő kritikát fogalmazott meg a keynesi makroökonometriai modellekkel, azok gazdaságpolitikai elemzésre és elörejelzésre való alkalmasságával kapcsolatban. Lucas szerint a keynesi ökonometriai modellek által számszerüsített monetáris és költségvetés-politikai multiplikátorok azért nem érvényesülnek a jövőre vonatkozóan, mert a gazdasági szereplök racionálisan várakoznak, és döntéseikkel alkalmazkodnak a kormányzat élénkítési akcióihoz. Ennek következtében a korábban becsült multiplikátorértékek is szükségképpen módosulnak. Két fontos következtetést fogalmazott meg ez alapján: 1. a kormányzati gazdaságpolitikai akciók hatástalanok, 2. csak azok a modellek elfogadhatóak (tekinthetők tudományosnak), amelyek racionális várakozásokon alapulnak.

Lucas ezen megállapításai jelentősen befolyásolták a makroökonómia hetvenes évek utáni fejlődését, ugyanakkor ez az irányváltás teljesen elhibázottnak bizonyult. A keynesi alapú makroökonometriai modellek ugyanis nem azért váltak használhatatlanokká, mert figyelmen kívül hagyták a racionális várakozásokat, hanem azért, mert maga a vállalt feladat volt kivitelezhetetlen. Érdemes e helyütt felidézni Keynes polémiáját Tinbergennel az ökonometriai modellezés lehetőségeiről (Tinbergen [1932], [1940] és Keynes [1939]). Keynes ahelyett, hogy meghatódott 
volna azon, hogy az elmélete alapján ökonometriai modelleket állítanak össze, élesen bírálta a vállalkozást, azt hangsúlyozva, hogy a gazdasági folyamatok olyan bizonytalanságokat tartalmaznak, amelyek valószínüségeloszlását nem ismerhetjük, s az erre vonatkozó nem tudásunk nem helyettesíthető azzal a feltevéssel, hogy „mindkét irányban egyforma valószínűséggel tévedhetünk” (Keynes [1965] 174. o.). Így tehát Lucas bírálata valójában nem a keynesi elméletet érintette, hanem csak annak egyik hibás interpretációját. Mégis innen datálható Keynes elméletének fokozatos kiszorulása a makroökonómiából.

A keynesi indíttatású ökonometriai modellre építő gazdaságpolitikai elemzés és elörejelzés kudarca azért volt elkerülhetetlen, mert nyilvánvalóan nem érvényesült az ökonometriai modellezésért Nobel-díjjal jutalmazott Klein [1971] kettős követelménye, nevezetesen hogy 1. a modell jól reprezentálja a gazdaságot, 2. a gazdaság szerkezete legyen stabil, időben ne változzon. Ugyanis a makrogazdaság egy olyan nyitott rendszer, amely állandó mozgásban van: a szereplök száma és összetétele változik, állandóan új eljárások jelennek meg, változnak a gazdasági intézmények és a működési szabályok. Mindez odavezet, hogy a becslés időszakához képest az előrejelzés időszakában már egészen más meghatározói lesznek a kiemelten fontos makrováltozóknak.

A gazdasági szerkezet változékonyságával természetesen a Cowles Commision ökonométerei is tisztában voltak (az ebből adódó nehézségre már az ötvenes években felhívták a figyelmet), azonban nem nagyon sokat tudtak tenni ellene. A szükségszerüen bekövetkező sokfajta változás közül csak az egyik az, amelyet Lucas kiemelt: a kormányzati akciók várható hatására válaszként a gazdasági szereplők reakciói is változnak. Kétségkívül igaz, hogy a piaci résztvevők várakozásainak idő közbeni változása befolyásolhatja a makroszintü teljesítményeket. De ez csak egyetlen elem a sok, folyamatosan módosuló hatótényező közül. Nem véletlen, hogy Sims és szerzőtársai [1982] az akkora már szép karriert befutó Lucas kritikáját mindössze egy alkalmi lábjegyzetnek értékelte a gazdaságpolitikai modellezés irodalmában.

A későbbi időszakban a fejlett világ makroökonómusai többször is tanúi lehettek, hogy a kormányzat monetáris és fiskális akciók egyáltalán nem hatástalanok, ahogyan pedig azt a racionális várakozások tézise megkövetelné. (Persze ezek az akciók olyan hatásosak sem voltak, mint amit a keynesi alapokon álló modellezők megjósoltak vagy elvártak.) Mégis a racionális várakozások elmélete és becslési gyakorlata páratlan gyorsan elterjedt a makromodellezők körében, s teljesen kiszorította a keynesi makromodelleket. A siker titka az az ígéret volt, hogy a racionális várakozások alkalmazása garantálja, hogy a gazdaságpolitikai elemzések és előrejelzések torzításmentesek, korrektek lesznek (szisztematikus előrejelzési hibát nem tartalmaznak), ugyanis a racionális várakozásokat alkalmazó modellek megfelelően ki tudják szürni a gazdaságpolitikai változásokból adódó módosításokat, és így a gazdaság müködését ténylegesen befolyásoló tényezőket ragadja meg és korrekt módon számszerűsíti a hozzájárulásukat. Ezek a modellek a makrofolyamatokat a gazdasági szereplők optimalizáló magatartásából származtatják, amelyek azokon a stabil tényezőkön (ízlések, preferenciák, technológiák, szokások) alapulnak, amelyeket sem a gazdaságpolitika és semmilyen más külső tényező nem képes megváltoztatni. A stabil fundamentumokra épülő modellek garantálják a torzítatlan 
becslést. Szokták ezeket a modelleket strukturális modelleknek is nevezni, utalva arra, hogy a keynesi makromodellekkel ellentétben ezek a modellek a gazdaság mély, stabil alapszerkezetét ragadják meg, s így a gazdaságpolitikai változások nincsenek hatással a becsült paraméterek nagyságára.

A baj nem az volt, hogy a keynesi nagy makroökonometriai modelleket kiszorították az újklasszikus modellek, hiszen azok valóban hibás alapokon álltak. Sokkal inkább az, hogy vele együtt Keynes makroelmélete is margóra került, mégpedig egy ugyancsak hibás alapokon álló elmélet, a racionális várakozások térnyerése következtében. Az egyre gyülő becslési tapasztalatok ugyanis azt mutatták, hogy a racionális várakozásokon alapuló előrejelzési modellek korántsem voltak olyan jók, mint azt ígérték az újklasszikusok, és egyáltalán nem látszottak hatékonyabbaknak, mint a korábban használt nagy ökonometriai modellek.

Hogy valami nagyon nincs rendben ezekkel a modellekkel, az az újklasszikus ökonométerek elött sem lehetett hosszú ideig titok. Ezt mutatja Thomas Sargent öszinte önvallomása arról, hogy néhány év tapasztalata után kiderült, hogy bizony az ö racionális várakozásokon alapuló modelljeik sem teljesítettek jobban, mint az általuk bírált keynesi modellek. Az ökonometriai modellbecslések hatékonyságának összehasonlítására szolgáló likelihood-arány próba (amely itt azért kiemelt fontosságú, mert a racionális várakozási egyensúly egy likelihood-függvény, amelyet maximalizálni kell) sok jónak gondolt modelljüket utasította vissza. Ök azonban a megfelelö következtetések levonása helyett, elkendőzve a hibákat, a kalibráláshoz folyamodtak. A kalibrálás arra szolgált, hogy megnyugtassa a szakmát, hogy ugyan az alkalmazott modellek nem korrektek, de mégis alkalmasak gazdaságpolitikai elemzésre (Evans-Honkapohja [2005] 567-568. o.).

A mindennapi gyakorlat szintjén pedig úgy próbálták palástolni e modellek gyenge elöre jelző képességét, hogy az eltéréseket a véletlen sokkokra fogták, arra hivatkozva, hogy normál esetben a gazdaság a hosszú távú egyensúlyi pályáján mozog, erről csak a sokkok téríthetik le. A racionális várakozáson alapuló modellek természetszerủen pontosan tudják számszerüsíteni és előre jelezni is ezt az egyensúlyi pályát. Ha a valóságos érték eltér az előre jelzettől, akkor az csak a véletlen zavaró hatások miatt alakulhatott ki. Így aztán garantáltan mindig helyesnek bizonyultak az előrejelzések, mert mindig találhatók voltak megfelelő irányú és nagyságú sokkok, amelyekre rá lehetett fogni az eltérést. S ne legyenek kétségeink: nem volt és nincs az a nagy becslési hiba, amit ne lehetne valamilyen konkrét külső sokkra ráterhelni. Ez annál is inkább könnyü, hiszen nincs egzakt mércénk arra nézvést, hogy egy konkrét sokk pontosan milyen mértékben módosítja a makrováltozók értékét. Ily módon még az olyan nagy előrejelzési hibák is, mint a 2008-2009-esek, ráfoghatók a véletlenre, amint azt Lucas [2009] meg is tette.

\section{Lehetséges-e torzítatlan (hatásos) gazdasági elörejelzéseket adni?}

E kérdésre az a rövid válasz, hogy nem, legalábbis abban az értelemben bizonyosan nem, amely becslöfüggvény (modellbecslés) alapján egy értéket és egy konfidencia-intervallumot határoz meg. A kategorikus elutasítás azon alapszik, hogy 
a gazdasági folyamatok nem olyan természetűek, mint amelyekre a statisztikaiökonometriai modellek alkalmazhatók lennének. A statisztikai becslések ugyanis szabályosan ismétlődő tömegjelenségekre vonatkoznak, a gazdaságban azonban nem jellemzőek ilyen típusú jelenségek.

- Hiába idézzük fel, hogy a gazdaságban nagyszámú termelő és fogyasztó tevékenykedik és hozza meg folyamatosan a döntéseit időszakról időszakra, ez mégsem az, amire a becslésekhez szükség lenne. Ugyanis ezek a gazdasági szereplők távolról sem homogének, hanem nagyon is heterogének, számuk és összetételük állandóan változik. És köztük különféle (véletlen vagy tartós) kapcsolatok alakulnak ki, amelyek rendre más és más helyzeteket alakítanak ki. A gazdaság szerkezete éppen ezért igen változékony, a strukturális instabilitás meghatározó kísérője a makrogazdasági idősoroknak (Stock-Watson [1996]).

- Az egyes időszakok eredményei nem pontosan ugyanannak a rögzített rendszernek az összevethető realizációi, hanem egyedi, csak arra az egyetlen helyzetre jellemző, egyedi adatok sora. A gazdaság folyamatosan müködik, nem a megfigyelési időszakhoz igazítva indul tiszta lappal, s nem is hagy tiszta lapot az időszak végére. Az adott időszak teljesítményét jelentősen befolyásolja, hogy milyen a rendszer időszak eleji állapota, milyenek az induló készletek, a rendelkezésre álló tényezők mennyisége, minősége stb. S ezek mind jelentősen függnek attól, hogy milyen volt a korábbi időszak gazdasági teljesítménye. A folyamat tehát nem trendfüggő, hanem sokkal inkább útfüggő.

- Azért sem tekinthetö tömegjelenségnek a gazdasági folyamat, mert tudattal rendelkező emberek alakítják a folyamatokat. S ezek az emberek valamilyen módon figyelembe veszik a múltbeli tapasztalataikat, valamilyen mértékben tanulnak azokból, $\mathrm{s}$ így a mindenkori tudatállapotuk hatással lesz a döntéseikre. Lassan, de folyamatosan alkalmazkodnak a változó körülményekhez, s ezzel maguk is hozzájárulnak a folyamatos változáshoz (lásd bővebben Soros [2001] reflexivitási elméletét). Ráadásul az egyének tudati állapotát nemcsak a múltbeli tapasztalatok, hanem az egymás közötti információcserék, egymásra hatások is befolyásolják. Így alakul ki és változik a divat, jönnek létre különféle rögeszmék, vagy így keletkeznek a pánikok is.

- A tömegjelenségek esetében - éppen a szabályszerü ismétlődések miatt - meghatározható a véletlen jellege, azonosítható a folyamatot leíró valószínűségeloszlás típusa és paraméterei. Ismertek a folyamat lehetséges kimenetei és azokra vonatkozóan empirikus gyakoriságok gyüjthetők. A gazdasági folyamatok sztochasztikus jellege azonban többnyire nem a beazonosítható véletlen, hanem a bizonytalanság következménye. Bizonytalanság esetén nem ismerjük a lehetséges kimeneteket, nem tudunk tapasztalati gyakoriságokat rendelni hozzájuk, egyszóval nem ismerjük a folyamat valószínűségeloszlását és/vagy annak jellemzőit (például a Cauchyeloszlásnak nincsen várható értéke és szórása Mérő [2014] 54. o.).

Az ökonometria azonban segít magán, ha nem talál, akkor előállít számszerüsíthető véletlent. Az ökonometriai vizsgálatok az idősorokból először kiszűrik a trendet, majd ezt követően a ciklikus hatást és ezután a reziduumot tekintik a véletlen hatásának (becslési hibának). A szűrők konkrét formájára vonatkozóan azonban nem 
rendelkeznek a priori, elméletileg megalapozott ismeretekkel, s ezek híján azokat a konkrét formákat tekintik megfelelő trendnek és ciklusnak, amelyek alkalmazásával a maradéktag jól viselkedő véletlen lesz (vagyis nulla várható értékü és konstans szórású normális eloszlású valószínűségi változó). Ez az eljárás azonban nem megtalálja a gazdasági folyamatokban benne rejlő trendet és ciklust, hanem ellenkezőleg, belecsempészi őket azáltal, hogy az egész eljárás azt tételezi, hogy a folyamatnak van egy céliránya, amely felé szüntelenül törekszik, s amelytől csak időlegesen tudják eltéríteni a külső, zavaró tényezők. Az iménti becslési logikának a következménye, hogy a becslési hibát szükségképpen külső zavaró tényezőnek kell tekinteni, mert a tényadatok csak azért térhetnek el a becslőfüggvény által rögzített nagyságoktól, mert valami megzavarta a törvényszerűség érvényesülését. S mivel a jó (torzítatlan) becslés kritériuma, hogy ne tartalmazzon szisztematikus hibákat, ezért nemcsak a becslési hiba, hanem a véletlen is jól viselkedő lesz. Vad véletlenek, szélsőséges változások (a Talebféle feketehattyú-jelenségek, Taleb [2012]) ebbe a logikába nem férnek bele, miközben a valóságban ilyenek bizony elég gyakran felbukkannak a pénzügyi és a reálgazdasági válságok képében (Mandelbrot-Hudson [2004]).

A nem normális eloszlású, vad véletlenek megjelenése sokkal nagyobb gondot jelent az ökonometria számára, mint ahogyan azt az első látásra gondolnánk. A problémát ugyanis nem lehet azzal elintézni, hogy az ökonometriai modellek elörejelzéseinél valamivel nagyobbra vesszük a konfidencia-intervallumot, hogy beleférjenek a komolyabb kilengések is. Ez távolról sem elég, mert ilyen esetben maga a becslési eljárás (legkisebb négyzetek módszere) válik hibássá, hiszen szisztematikus hibát tartalmaz. A becslés azért válik torzítottá, mert a becslőfüggvény meghatározása úgy történik, hogy a tényadatokhoz minél pontosabban illeszkedjenek a becsült értékek, s így az eltérés szükségképpen normális eloszlású lesz. A vad véletlen miatti kiugró értékeket ez a becslési eljárás úgy értelmezi, hogy a becslöfüggvény paramétereit magasabbra vagy alacsonyabbra kalibrálja, mint amekkora az valójában, a normális eloszlású hibatag doktrínájának a fenntartása miatt. Paul Cootner, az MIT professzora Mandelbrotra és az ő vad véletleneire hivatkozva, azt állította, hogy a statisztikai eszköztárunk majdnem teljes egészében idejét múlttá vált, beleértve a legkisebb négyzetek módszerét, spektáranalízist, a maximum likelihood-módszert, a mintavételi eljárásokat és a zárt eloszlásokat (MandelbrotHudson [2004] 29. o.). Az igazság kedvéért meg kell említeni, hogy vannak olyan - (általánosított) autoregresszív feltételes heteroszkedaszticitás (Autoregressive Conditional Heteroskedasticity, ARCH és Generalized Autoregressive Heteroskedasticity, GARCH) - becslési eljárások, amelyek kifinomultabban kezelik a véletlent: figyelembe veszik a sokkok tovagyürüző hatását, és nem követelik meg a szórásuk állandóságát (Palágyi [2003]). Ez azonban nem változtat azon a gyakorlaton, hogy a becsléseket végzők (és a makroökonómia-tananyagokat készítők) túlnyomó többsége OLS-becsléseket használ, minden korlátozó megjegyzés nélkül.

Ilyen és ehhez hasonló indokok alapján állítják a posztkeynesi közgazdászok, élükön Paul Davidsonnal, hogy a gazdasági folyamatok nem ergodikusak, hanem útfüggők, következésképpen nem lehet meghatározni az adatgeneráló folyamataikat (Davidson [1991]). Az ergodikus folyamatok esetében az idősor tetszőleges részéből 
vett különböző minták statisztikai jellemzői (átlag, szórás) megegyeznek. Az ilyen folyamatok esetében valóban van lehetőség az elörejelzésre, mert egy adott időpontból akár hátrafelé, akár elöre meghatározhatók az egyes időpontokhoz tartozó értékek (pontosabban azok várható értéke), a becslöfüggvény identifikálása után. Ha a gazdaságban jellemző lenne az ergodicitás, akkor igen egyszerű lenne az előrejelzés is, hiszen csak egyszer kellene meghatározni az egyes makrováltozókra vonatkozó adatgeneráló folyamatot, utána már menne minden, mint a karikacsapás. Nem is lenne szükség különféle makroelemző és elöre jelző intézetekre, elég lenne az egész országban egyetlen, kis létszámú ökonometriai csoport és egy jó számítógép, s így a hibátlan (szisztematikus hibát nem, legfeljebb csak véletlen hibát tartalmazó) becslések könnyen elérhetővé válnának mindenki számára. Talán nem véletlen, hogy valami ilyenféle helyzetet vizionál a racionális várakozások elmélete is, amikor arról akar meggyőzni bennünket, hogy a laikusok is könnyen hozzáférhetnek az optimális döntéseikhez szükséges információkhoz.

A gazdasági folyamatok nem ergodikus jellegét az ökonométerek szerint könnyen ki lehet küszöbölni, hiszen szinte minden gazdasági idősor logaritmusa integrált, vagyis első vagy második differenciája már bizonyosan stacionárius. A már régóta ismert egységgyökpróbák segítségével az idősorok integráltsági fokát könnyen meg lehet állapítani, és így azt is, hogy a változók milyen differenciája mellett lesz stacioner és így becslésre alkalmas. Valójában azonban nem ennyire egyszerủ a helyzet, mert a vizsgálandó problémák többségénél egyáltalán nem mindegy, hogy az eredeti adatsorok vagy - mondjuk - a második differenciáik között próbálunk számszerüsíthető összefüggést találni. Tovább bonyolítja a helyzetet, hogy a stacionaritás biztosításával még nem tudhatjuk le az ergodicitás problémáját, mivel ez utóbbi erősebb kritériumot jelent. Vagyis a stacionárius folyamatok nem szükségképpen ergodikusak (Hamilton [1994] 47. o.). Az ergodicitás fennállásához még további feltételeknek is teljesülniük kellene.

Az újklasszikus közgazdaságtan logikáját követve persze könnyen eljuthatunk az ergodikus gazdasági müködéshez. A gazdasági rendszer akkor lesz valóban ergodikus, és ezért akkor válik lehetségessé a torzítatlan elörejelzés, ha

- a piaci rendszer tökéletesen müködik, az egyes periódusok végén nem maradnak egyensúlytalansági helyzetek, a következö periódusok kezdetére teljesen kitisztul a piac, vagyis az előző időszakkal megegyező helyzetből indulhat a következő időszak,

- továbbá nincsen technikai fejlődés (vagy ha mégis van, akkor az egyenletes, azonnal és tökéletesen szétterjed), s végül

- ha a várakozások racionálisak (végtelen időhorizontra), tehát nincs tanulási folyamat, az egyes szereplők ismeretszintje minden időszakban ugyanaz (mert már minden releváns ismerettel rendelkeznek az egész időszak elején).

Csakhogy az ergodicitás feltételezi a racionális várakozásokat, ami pedig csak akkor lehetséges (kivitelezhetö), ha rendelkezünk olyan modellel, amelyből torzításmentes (szisztematikus hibával nem terhelt) előrejelzéseket tudunk produkálni. Ezt pedig csak akkor lehet garantálni, ha a piaci müködés tökéletes, és a várakozások racionálisak. S ezzel visszatértünk a kiindulóponthoz, körkörös 
érveléshez jutottunk: racionális várakozások akkor lehetségesek, ha feltesszük, hogy a várakozások racionálisak.

Visszatérve a valóságos gazdasági élethez, ahol a folyamatok nem ergodikusak, és a becslés számára az idősorokat nem is lehet ergodikussá transzformálni, ott a megbízható előrejelzés feladatát sem lehet egyetlen ökonometriai laboratórium segítségével megoldani. Minden országban több elörejelzéssel foglalkozó intézet van, és gyakran markánsan különböző prognózisokat adnak, s igen sokszor egyiküknek sem lesz igazuk, mert a gazdaság valami egészen különlegeset produkál. A sok-sok elörejelzési hiba és tévedés azonban nem jelenti azt, hogy nem érdemes előrejelzéssel foglalkozni, csak nap mint nap azt a régi igazságot erösíti meg, amit Niels Bohr - jellemző módon egy fizikus és nem közgazdász - fogalmazott meg: „Az előrejelzés igen nehéz feladat, különösen, ha a jövőre vonatkozik." Ez a kijelentés arra utal, hogy ismereteink és tudásunk milyen ingatag lábakon állnak, mennyire bizonytalanok. Kétféle nem tudás jön itt számításba: egyfelől a „tudjuk, hogy mit nem tudunk”, másfelöl pedig a „nem tudjuk, hogy mit nem tudunk” típusú (Hendry-Clements [2001]). A makroökonometria rendre elfeledkezik a második fajta nem tudásról, s csak az elsőre koncentrál, amelynél pedig azt tételezi fel, hogy ugyan pontosan nem tudjuk meghatározni a véletlen eseményeket, de jól ismerjük a véletlen természetét (az események valószínűségeloszlását). Az előrejelzéseket rendszeresen készítő szakembereknek azonban állandóan szembesülniük kell a második típusú nem tudással és az ebből következő bizonytalansággal.

Az előrejelzésekkel foglalkozó intézetekben, jóllehet több makromodellt is használnak, mégsem a modellbecslések eredményei alapján határozzák meg az elörejelzéseket. A modellek fontos segédeszközök, de elsődlegesen nem elörejelzésekre használják őket, hanem arra, hogy konzisztensek legyen az előrejelzéseik. Mindjárt érthetőbbé válik ez a különösnek tűnő gyakorlat, ha a problémát a makromüködés sajátosságai alapján közelítjük meg. Amint arra már a korábbiakban is utaltunk, a bonyolult és szüntelen változó gazdaságban nincs stabil, letisztult oksági viszonyrendszer, az egyes időszakokban igen eltérő lehet a hatótényezők köre. Erre a makroelemzők is rájöttek, s annak érdekében, hogy jobb előrejelzést tudjanak készíteni, nem hagyatkozhatnak egy olyan modell becslésére, amelyben „be vannak drótozva” az oksági viszonyok. Sokkal inkább azt próbálják megállapítani, hogy az adott időszakban éppen melyek a meghatározó tényezők, milyen tendenciák uralkodnak. Az elemző-elörejelzők tehát összeraknak egy történetet, azt rekonstruálandó, hogy mi történt a közelmúltban és miért éppen az történt. Majd ennek a helyzetértékelésnek az alapján kidolgoznak különféle forgatókönyveket a jövőre vonatkozóan, amelyek nevesítik és számszerüsítik a legerőteljesebbnek vélt tendenciákat. S csak ez után kapnak szerepet a modellek, amelyek ezeket a forgatókönyveket konkretizálják, a mérlegösszefüggések alapján konzisztenssé teszik őket, s megmutatják, hogy milyen következményei lesznek (lehetnek) a közvetlenül nem érintett területeken. A forgatókönyvek közötti választás ezen várható hatások és következmények mérlegelése után történik meg.

Az elörejelző munka iménti leírása sokakban kelthet ellenérzéseket, legelsőként a tagadást: nem, ez biztosan nem így van, a tanulmány írója rosszul tudja, komoly tudós 
emberek nem hagyatkoznak megérzésekre és különféle forgatókönyvekre, hanem szigorúan a tudományos elmélet alapján álló egzakt modellbecslési eredményeket közölnek csak. A másik ellenérzés a lekicsinylés, a leértékelés lehet: hát ha így készülnek az elörejelzések, akkor az nem nagy dolog, pusztán szemfényvesztés, hiszen bárki tud ilyent készíteni, ha nagyon akar. Valójában azonban az elemző-előre jelző munka nagyon komoly intellektuális feladat, temérdek sok háttérismeretre és tapasztalatra van szükség, igen intenzív gondolkodást igényel annak feltárása, hogy mi is történt valójában a gazdaságban a közelmúltban, mik voltak a döntő, meghatározó elemek. Ennél már csak annak meghatározása a nehezebb, hogy mely tényezők és miként fogják a közeljövő történéseit determinálni. Ennek megfelelően a modellalkotó és előre jelző munka valahol a tudomány és a művészet határán áll.

\section{Összegzés helyett}

Hendry [1980] szerint Keynes közel járt annak kinyilatkoztatásához, hogy a közgazdasági elméletek ökonometriai módszerekkel nem tesztelhetők (396. o.). De ebben az esetben a közgazdaságtan megszünne tudomány lenni, s Keynes ezt nyilván nem akarhatta. Az én olvasatomban egészen más értelmet nyernek ezek az elemek: Keynes valóban kizárta az ökonometriai modellek alkalmazhatóságát a (makro)közgazdaságtanban, de ez nem jelenti, hogy a tudományos státusát is elvitatta volna. Csupán annyit jelent, hogy a közgazdaság-tudományt társadalomtudománynak tekintette, és ezért nem tartotta perdöntő kritériumnak a természettudományos verifikációs módszerek alkalmazhatóságát.

Az ökonometriai nagy utat tett meg, míg a segédtudomány státusból vezető, paradigmaalkotó szerepre küzdette fel magát a makroökonómiában. Az újklasszikus makroökonómia ma egészen más, mint volt 30-40 éve, felépítését és tárgyalásmódját tekintve lényegesen egzaktabb lett, módszertanilag sokkal igényesebbé vált, a laikusok számára pedig csodálatra méltóvá. A nagy átalakulás során azonban egyre inkább háttérbe szorultak a tudományszak alapcélkitüzései: az ökonometria segítségével feltárni a gazdasági mủködés meghatározó elemeit, megfogalmazni az időszak alapvető tendenciáit, a gazdaságpolitika számára fogódzókat nyújtani, felvázolni a makrogazdasági jövő lehetséges forgatókönyveit. Mivel ezeket a feladatokat a 2008-as válság és az utána következő időszak tanúságai szerint sem tudta teljesíteni az ökonometria által dominált makroökonómia, a nem szakmabeli emberek bár továbbra is csodálják, de igazából nem szeretik, és nem is tartják hasznos tudománynak.

Az ökonometriának - éppen azért, hogy az újklasszikus makroökonómiába való kirándulás negatív bélyegétől megszabadulhasson - más alkalmazási területek után szükséges néznie. A makrogazdasági idősorok és az RBC és DSGE makromodellek helyett keresztmetszeti vagy paneladatok elemzését kellene előtérbe helyeznie. További lehetőségek tárulnak fel azáltal, hogy a makroökonómia valódi (nem újklasszikus!) mikromegalapozása feltartóztathatatlanul tör előre, így tehát szükségessé válik a gazdasági szereplők viselkedésének modellezése és empirikus megalapozása, különös tekintettel a nem racionális viselkedésre és várakozásokra, 
valamint a heterogén gazdasági szereplők figyelembevételére. Ezentúl az ágensalapú szimulációs modellek eredményeinek értékelése és elemzése ugyancsak új feladatot jelenthet az ökonometria számára.

\section{Hivatkozások}

Borio, C.-Disyatat, P.-Juselius, M. [2013]: Rethinking potential output: Embedding information about the financial cycle. BIS Working Papers, No. 404.

Colander, D. [2005]: The Making an Economist Redux. Journal of Economic Perspective, Vol. 19. No. 1. 175-198. o. http://dx.doi.org/10.1257/0895330053147976.

Davidson, P. [1991]: Is Probability Theory Relevant for Uncertanty? A Post Keynesian Perspective. Journal of Economic Perspective, Vol. 5. No. 1. 129-143. o. http://dx.doi. org/10.1257/jep.5.1.129.

Evans, G. W.-Honkapohja, S. [2005]: An Interview with Thomas J. Sargent. Macroeconomic Dynamics, 9. Vol. 4. 561-583. o. http://dx.doi.org/10.1017/s1365100505050042.

Hamilton, J. D. [1994]: Time Series Analysis. Princeton University Press, Princeton.

HendRY, D. F. [1980]: Econometrics. Alchemy or Science. Econometrica, Vol. 47. No. 188. 387-406. . o. http://dx.doi.org/10.2307/2553385.

Hendry, D. F.-Clements, M. P. [2001]: Economic Forecasting: Some Lessons from Recent Research. Working Paper Series, European Central Bank, No. 82.

Hodrick, R.-Prescott, E. C. [1997]: Postwar U.S. Business Cycles: An Empirical Investigation. Journal of Money, Credit, and Banking, Vol. 29. No. 1 1-16. o. http://dx.doi. org/10.2307/2953682.

Keynes, J. M. [1939]: Professor Tinbergen's Method. A Method and its Application to Investment Activity. Economic Journal, Vol. 49. No. 195. 558-568. i.

Keynes, J. M. [1965]: A foglalkoztatás, a kamat és a pénz általános elmélete. Közgazdasági és Jogi Könyvkiadó, Budapest.

KLeIn, L. R. [1971]: An Essay on the Theory of Economic Prediction. Markham Publishing Company, Chicago.

LuCAS, R. [1976]: Economic Policy Evaluation: A Critique. Carnegie-Rochester Conference Series on Public Policy, 1. 19-46. o. http://dx.doi.org/10.1016/s0167-2231(76)80003-6.

Lucas, R. [2009]: In defense a dismal science. Economic Focus. The Economist, augusztus 8. 63. o.

Mandelbrot, B.-Hudson, R. L. [2004]: The (Mis)behavior of Markets. A Fractal View of Financial Turbulence. Basil Books, New York.

Mellár Tamás [2015]: Szemben az árral. Akadémiai Kiadó, Budapest.

MÉRő LÁszló [2014]: A csodák logikája. A kiszámíthatatlan tudománya. Tercium Kiadó, Budapest.

MNB [2007]: Jelentés az infláció alakulásáról. Magyar Nemzeti Bank, Budapest, május.

Muth, J. F. [1961]: Rational Expectations and the Theory of Price Movements. Econometrica, Vol. 29. No. 3. 315-335. o. http://dx.doi.org/10.2307/1909635.

Palágyi Zoltán [2003]: Pénzügyi idősorok elemzése a Lévy-hatvány GARCH-modellel. Statisztikai Szemle, 81. évf. 7. sz. 571-587. o.

QuandT, R. E. [1988]: The Economics of Disequilibrium. Basil Blackwell, New York.

RAPPAI GÁbOR [2014]: Bevezetés a pénzügyi ökonometriába. Egyetemi jegyzet, PTE KTK Pécs. 
SEAter, J. J. [1993]: Ricardian Equivalence. Journal of Economic Literature, Vol. 31. No. 1. 142-190. o.

Sims, C. A.-Goldfeld S. M.-Sachs J. D. [1982]: Policy Analysis with Econometric Models. Brookings Papers on Economic Activity, No. 1. 107-164. o. http://dx.doi. org/10.2307/2534318.

Soros György [2001]: A nyílt társadalom, avagy a globális kapitalizmus megreformálása. Scolar Kiadó, Budapest.

Stock, J. H.-WATson, W. W. [1996]: Evidence on structural instability in macroeconomic time series relations. Journal of Business and Economic Statistics, Vol. 14. No. 1. 11-30. o. http://dx.doi.org/10.1080/07350015.1996.10524626.

Taleb, N. N. [2012]: A fekete hattyú avagy a legváratlanabb hatás. Gondolat Kiadó, Budapest.

Tinbergen, J. [1932]: Ein Problem der Dynamik. Zeitschrift für Nationalökonomie, 3. 169-184. o. http://dx.doi.org/10.1007/bf01322552.

Tinbergen, J. [1940]: On a Method of Statistical Business Cycle Research. A Replay, Economic Journal, Vol. 50. No. 196. 141-154. o. http://dx.doi.org/10.2307/2225763.

VARGA BALÁzs [2010]: Időben változó együtthatójú ökonometriai modellek. Corvinus Egyetem Matematikai-közgazdaságtan és Gazdaságelemzés Tanszéki Tanulmányok, 4. sz. 